\title{
Notary Role In The Process Of Establishment Limited Liability Company (PT)
}

\author{
Rino Iqbal Akta Pratama1, ${ }^{1}$ Asep Suherdin ${ }^{2}$ and Gunarto ${ }^{3}$
}

Abstract. The purpose of this study were 1) To determine the role of the notary in the process of setting up a Limited Liability Company (PT), 2) To determine whether the obstacles faced by the notary in the process of setting up a Limited Liability Company (PT) and the solution.

The method used in this research is empirical juridical approach, juridical (legal viewed as the norm or das sollen), because in discussing the problem of research using legal materials (both the written law and the unwritten law or good legal materials primary or secondary law). Specifications research used in this research is descriptive, as explained, describe or disclose the legislation in force associated with the theories of law and positive law enforcement practice concerning these issues.

Based on the results of this study concluded that 1) According to the Minister of Justice of the Republic of Indonesia No. M.01-PR.08.01 1996 on Procedures for Submission of Application and Approval of Deed of Establishment of the Limited Liability Company, that pengesahaan establishment of PT may be made by the founders together or proxies, can also by a notary, so there is no necessity notaries as public officials who approve their establishment of limited liability companies, but these roles can be carried out by the founder of the company. 2) Barriers faced delay problems often arise.For the notary, will make the process inefficient. Probes for the ongoing process difficult because of the lack of an online system that can monitor the manufacturing process. Solutions to overcome the obstacles faced by the notary in the legalization of the establishment Company Limited is a Limited Liability Company in the legalization of the establishment can be overcome with the Legal Entity Administration System electronically, as a matter of time and efficiency in monitoring the rights to this process.

Keywords: Role; Notary Public; Limited Liability Company (PT)

\section{Introduction}

Society in general and in the community in the business world in performing activities or a legal act require the services and the role of a notary, it is against the backdrop of the need for proof in writing, where the notary is able to meet these needs, because the notary has a function to create and provide documents (deed) authentic as strong evidence that are expected to provide legal protection for the holder and the parties concerned to the document (deed) is.

It thus as described in Article 1 Rule Notary who give provisions on the definition of a notary as well as the tasks of a notary, namely: "Notary is a public official (oepenbaar ambtenaar) which is the only one authorized to make the deeds of all actions, agreements and decisions by general legislation may be required, or the or she stated in a letter authentic, set the date, save the deed and provide grosse (valid copy), copy and quotation, all of it throughout the making of the deed was not also required to be a special officer or obligations".

\footnotetext{
${ }^{1}$ Student of Master of Notary Law, Faculty of Law, UNISSULA Email: iqbalrino4343@gmail.com

${ }^{2}$ Student of Master of Law, Faculty of Law, UNISSULA Email: asepsuherdin6@gmail.com

${ }^{3}$ Professor of the Faculty of Law, UNISSULA
} 
As well as in Article 1 of Notary Act No. 30 of 2004 concerning the definition mentioned Notary, namely: "Notary is a public official authorized to make an authentic deed and other authorities referred to in this law.

Of Regulation Notary and Notary law above it can be concluded that the principal task of the notary is to make the deeds authentic, where the authentic act pursuant to Article 1870 BW (Burgelijk wetboek) provide to the parties who made an agreement that absolute, Therein lies the importance of the profession of notary, the notary is authorized to create a tool that is absolute proof by law, in the sense that what is mentioned in an authentic deed was essentially considered correct. It is very important for those who need a verification tool for a purpose, either for personal benefit or for the benefit of an undertaking that activity in the business field. ${ }^{4}$

Limited Liability Company (PT) is the establishment of economic activities most preferred at this time, because in addition to the accountability that is limited, Limited Liability Company also makes it easy for owners (shareholders) to divert the company (to everyone) to sell the entire share holding in the company, as well as other benefits. ${ }^{5}$

Indonesia itself has a Limited Liability Company Law (Company Law) No. 1 of 1995, which contains a complex of matters relating to the provisions of the Limited Liability when compared with the provisions contained in the Book of the Law of Commercial Law (Commercial code) is born first and is a product of Dutch colonial heritage law.

The role of the notary in the era of free trade in deed a limited liability company, particularly in terms of Foreign Direct Investment (FDI), are very important and are required to master a variety of disciplines, not just discipline notaries. This is because the notary is now faced with a complex problem, both as a result of economic development, political, social and cultural community as well as changes in laws and legislation. Today, with the opening of the business world in Indonesia for investment from domestic investors and foreign investors to invest in Indonesia, it will provide a considerable impact on the company that is mainly limited liability companies, including the role of the notary in carrying out the job of making authentic deed act for the interests of investors, especially with regard to the maintenance of a limited liability company and its related documents.

Of some forms of enterprise that exist in Indonesia, ${ }^{6}$ limited liability company is the most popular form of companies in the business and most widely used by the business / investor in carrying out business activities in various fields. In addition to having a clear legal basis as stipulated in Act No. 40 of 2007 on Limited Liability Company ${ }^{7}$, A limited liability company (PT) is also felt over the safety of the shareholders / owners of capital in the attempt. Running a business with container PT has some obvious advantages, namely the existence of limited liability for shareholders. Shareholder is

\footnotetext{
${ }^{4}$ R. Soegando Notodisoejo, 1982, Hukum Notariat Di Indonesia Suatu Penjelasan, Jakarta: CV. Rajawali, p 8

${ }^{5}$ Ahmad Yani dan Gunawan Widjaja, 2003, Perseroan Terbatas, Jakarta: PT. Raja Grafindo Persada, $\mathrm{p} 1$

${ }^{6}$ Companies can be divided into several categories: A. Judging from its capital origin: (i) in the country (DCI) is the national state enterprises and the private sector; (Ii) foreign (FDI) and foreign (mixed). B. Judging from the absence of legal entities: (i) form a legal entity such as Cooperative, Public Corporation (Perum-SOE) and Company Limited; (Ii) that the company is not a legal entity such as the Civil Alliance, Firm and CV (Commanditer Venotschap). Handri Raharjo, Company Law, cet. 1, (Yogyakarta: Pustaka Yustisia, 2009), p. 4-5.

7 Indonesia (A), the Limited Liability Company Law, Act No. 40 of 2007, LN No. 106 of 2007, Supplement No. 4756
} 
only responsible for a number of nominal value of shares he owned. In addition there are three (3) the dominant characteristic that PT is a form appropriate effort used in the development capital and is a major orientation of any business person or investor, namely:

- liability arising solely charged to the assets pooled in associations;

- mobility nature of the right to participation;

- the principle of maintenance through an organ.

Businesses operating in Indonesia, the majority of Indonesian citizens, many who use PT as a form of business, then the fact that the majority of PT today that have been established and / or have obtained the legal status of the authorized institution, wholly owned by Indonesian citizens and / or Indonesian legal entity, so that the entire capital of PT is derived from domestic investors. In accordance with applicable regulations, the PT that all holders of shares / capital comes from within the country did not obtain any facilities from the Government, so that the PT were called PT Non Facility, except PT are later want to invoke the facilities of the Government in accordance with the legislation that apply. Thus PT Non Facility is PT established without the use of any facilities. ${ }^{9}$ While the reverse if PT is partially or entirely derived from and owned by foreign investors who use investment facility, then the corresponding laws and regulations that apply to PT who use the facility called PMA.

It is thus important for the notary as a person (figuur) are descriptive captions are reliable, trustworthy, which provide strong evidence. Notaries perform their role to make the deeds PT must pay attention to and in accordance with Act No. 30 of 2004 concerning Notary ${ }^{10}$ and legislation related to the PT is concerned. In addition to a charge of making an authentic deed, the notary must be able to provide legal advice and explanation of laws to investors who still lay in the field of law relating to the deed he had done, and that should not be ruled also that the notary must be able to prevent trouble ${ }^{11}$ even disputes. The function and role of the notary in the movement of investment and national development increasingly complex today is certainly more widespread and growing, due to the smooth and legal certainty of the whole business run by people / investors are becoming more and more widespread, and it certainly can not be separated from service and legal product that is produced by a notary. Government and society as well as foreign investors / country certainly have the expectation that the services provided by notaries actually has a weight that can be relied upon, because speaking notaries also means talking about the authenticity of the document. $^{12}$

Based on the background of the problems mentioned above, it can be formulated problems are: (1) What is the role of the notary in the process of setting up a Limited Liability Company (PT) ?; (2) The resistance is facing a notary public in the process of establishing a Limited Liability Company (PT) and what's the solution?

\footnotetext{
${ }^{8}$ Salim HS and Budi Sutrisno, 2008, Hukum Investasi di Indonesia, ed. 1-2, cet. 1, Jakarta: Rajawali Pers, p. 171.

9 http://www.depkumham.go.id/NR/rdonlyres/PERMOHONANPTMELALUISISMINB AKUM.html, retrieved March 16, 2019

${ }^{10}$ Indonesia (B), Notary Law, Act No. 30 of 2004, LN No. 117 of 2004, Supplement No. 4432.

${ }^{11}$ Tan Thong Kie, Studi Notariat \& Serba-Serbi Praktek Notaris, Buku I, cet. 2 (rev), (Jakarta: Ichtiar Baru Van Hoeve, 2000), p. 162

${ }^{12}$ Ira Koesoemawati dan Yunirman Rijan, Ke Notaris, cet. 1, (Jakarta: Raih Asa Sukses, 2009), p. 23.
} 


\section{Research methods}

The method used in this research is empirical juridical approach, juridical (legal viewed as the norm or das sollen), because in discussing the problem of research using legal materials (both the written law and the unwritten law or good legal materials primary or secondary law). Empirical approach (law as a social reality, cultural or das sein), because in this study used primary data obtained from the field.

Specifications research used in this research is descriptive, ${ }^{13}$ as explained, describe or disclose the legislation in force associated with the theories of law and positive law enforcement practice concerning these issues.

\section{Discussion}

\subsection{The role of the notary in the process of setting up a Limited Liability Company (PT)}

With the enforcement of the Company Law, according to the provisions of Article 7 paragraph (6) of the Company Law, Limited Liability Company started legal status since the Deed of Establishment obtain approval from the Minister of Justice. The Company Law have provided legal certainty with regard to when the company started legal status. ${ }^{14}$

As with the Book of the Law of Commercial Law (Commercial code) which regulates the obligation to register and declare the deed of establishment of limited liability companies, accompanied by sanctions, then the Company Law also complements Article 7, paragraph (6) of the Article 21 and 22 on the obligation for Directors Limited liability Company to register and announce the Deed of Establishment of a Limited liability Company that has been approved by the Minister of Justice, even the obligation was also accompanied by sanctions under Article 23 of the Company Law. ${ }^{15}$ So regarding the registration and announcement of the company's Deed of Establishment was passed, the duty for the directors / founders, not a notary.

Based on an interview with Mr. Iwan Muhtadi, $\mathrm{ST}^{16}$, As Head of the Environment in Kendal that written permission from the environmental department has nothing to do with PMA. Because PT PMA must be a principal license from the Ministry. There are several PMA incoming environmental permits in Kendal about 20 PMA. The point which gave permission to the environment in Kendal no difference between PMA with regular PT.

The role of the notary in the legalization of the establishment Limited Company, as follows:

- The role of the notary begins at the moment of establishment Limited Liability Company, with the establishment of the Deed of Establishment Company Limited by a notary, where the whole process is done manually;

- Regarding its operation is governed by Decree of the Minister of Justice of the Republic of Indonesia No. M.01-PR.08.01 1996 on Procedures for Submission of Application and Approval of Establishment Deed of Limited Liability Company;

\footnotetext{
${ }^{13}$ S. Margono, 2003, Metodologi Penelitian Pendidikan, Jakarta: Rineka Cipta, p. 37

14 Herman Susetyo, 2000, Perkembangan Pengaturan Hak-Hak pemegang Saham Dalam Perseroan Terbatas Di Indonesia, Thesis: Master of Law Universitas Diponegoro, p 68

${ }^{15}$ Herman Susetyo, p. 69

${ }^{16}$ Results of an interview with Mr. Iwan Muhtadi, ST, as the Head of the Environment in Kendal, on July $22,2019,14: 05 \mathrm{pm}$
} 
- Ratification of the establishment of limited liability companies, may be made by the founders together or by proxy, in this case the notary. (Article 1 of Decree of the Minister of Justice of the Republic of Indonesia No. M.01-PR.08.01 1996 on Procedures for Submission of Application and Approval of Establishment Deed Company Limited

\subsection{Barriers faced by a notary public in the process of establishing a Limited Liability Company (PT) and the solution}

In interviews with the General Legal Administration Mrs. Dr. Hj. Setyawati, $\mathrm{SH}, \mathrm{MH}^{17}$, Regions in Central Java, due to the regulations of the Ministry of Justice which indeed requires approval from BKPM before a company can be authorized as a legal entity. Obviously, coordination and consolidation between the Ministry of Justice and Human Rights and BKPM necessary so that the new regulations can be implemented. It is apparent that such provisions were made to facilitate the process of formation of the company in the context of FDI in Indonesia.

To make it easier to see the obstacles that occur in the legalization of the establishment Limited Company, as follows:

- Delay problems often arise, this is because the officers had to check one by one entering request, while the number of applications that go far more than the capacity of the existing officers. The risk of human large errorcukup because each data should be matched to the document which is quite a lot.

- For the notary, will make the process becomes inefficient because they have to check to the Ministry of Law and Human Rights, is because the whole process can only be done and monitored.

- Probes for the ongoing process difficult because of the lack of an online system that can monitor the manufacturing process.

- The process of ratification of the Deed of Establishment Company Limited which is done manually by Decree of the Minister of Justice No. M.01-PR.08.01 1996, based on the experience so far, it is difficult to be completed on time in accordance with the provisions of article 9, paragraph (2) of the Act No. 1 of 1995 (Company Law), ie within a period of 60 days (sixty) days after the application is received.

The solution to overcoming obstacles encountered in implementing the notary in the legalization of the establishment of Company Limited is a Limited Liability Company in the legalization of the establishment can be overcome with the Legal Entity Administration System electronically, as a matter of time and efficiency in monitoring the rights to this process.

\section{Closing}

\subsection{Conclusion}

- According to Minister of Justice of the Republic of Indonesia No. M.01-PR.08.01 1996 on Procedures for Submission of Application and Approval of Deed of Establishment of the Limited Liability Company, that pengesahaan establishment of PT may be made by the founders together or their proxies, can also by a notary, so do not there must notaries as public officials who approve their establishment of

\footnotetext{
${ }^{17}$ Results of interviews with Mrs. Dr. Hj. Setyawati, SH, MH as Public Law Administration in Central Java, on June 25, 2019, 13:15 pm
} 
limited liability companies, but these roles can be carried out by the founder of the company.

- Barriers faced delay problems often arise. For the notary, will make the process inefficient. Probes for the ongoing process difficult because of the lack of an online system that can monitor the manufacturing process. Solutions to overcome the obstacles faced by the notary in the legalization of the establishment Company Limited is a Limited Liability Company in the legalization of the establishment can be overcome with the Legal Entity Administration System electronically, as a matter of time and efficiency in monitoring the rights to this process.

\subsection{Suggestion}

- Limited Liability approval procedures of establishment, it should be the parties involved, especially in this notary truly knows every facet of the process, including on matters related to the use of the internet as a means.

- Obeying all the provisions in the legislation, always carefully and cautiously that the notary deed that made it true or based on the facts material to the creation of the smooth and the concept of legal certainty.

\section{Bibliography}

[1] Ahmad Yani dan Gunawan Widjaja, 2003, Perseroan Terbatas, Jakarta: PT. Raja Grafindo Persada

[2] Herman Susetyo, 2000, Perkembangan Pengaturan Hak-Hak pemegang Saham Dalam Perseroan Terbatas Di Indonesia, Tesis: Magister Ilmu Hukum Universitas Diponegoro Semarang

[3] Indonesia (A), the Limited Liability Company Law, Act No. 40 of 2007, LN No. 106 of 2007, Supplement No. 4756

[4] Indonesia (B), Notary law, Act No. 30 of 2004, LN No. 117 of 2004, Supplement No. 4432.

[5] Ira Koesoemawati dan Yunirman Rijan, 2009, Ke Notaris, cet. 1, Jakarta: Raih Asa Sukses

[6] R. Soegando Notodisoejo, 1982, Hukum Notariat Di Indonesia Suatu Penjelasan, Jakarta: CV. Rajawali

[7] S. Margono, 2003, Metodologi Penelitian Pendidikan, Jakarta: Rineka Cipta

[8] Salim HS dan Budi Sutrisno, 2008, Hukum Investasi di Indonesia, ed. 1-2, cet. 1, Jakarta: Rajawali Pers

[9] Tan Thong Kie, 2000, Studi Notariat \& Serba-Serbi Praktek Notaris, Buku I, cet. 2 (rev), Jakarta: Ichtiar Baru Van Hoeve

[10] Results of an interview with Mr. Iwan Muhtadi, ST, as the Head of the Environment in Kendal, on July 22, 2019, 14:05 pm

[11] Results of interviews with Mrs. Dr. Hj. Setyawati, $\mathrm{SH}, \mathrm{MH}$ as Public Law Administration in Central Java, on June 25, 2019, 13:15 pm 